\title{
Bacterial contamination of automotive fuels in a tropical region: the case of Costa Rica
}

Carlos E. Rodríguez-Rodríguez ${ }^{1,2}$, Evelyn Rodríguez-Cavallini ${ }^{1}$ \& Rigoberto Blanco ${ }^{3}$

1. Centro de Investigación en Enfermedades Tropicales y Laboratorio de Investigación en Bacteriología Anaerobia, Facultad de Microbiología, Universidad de Costa Rica, 2060 Costa Rica. Tel: (506) 2207 4364, Fax: (506) 2225 4384; carlos.rodriguezrodriguez@ucr.ac.cr; evelyn.rodriguez@ucr.ac.cr

2. Departament d'Enginyeria Química, Escola Tècnica Superior d'Enginyeria, Universitat Autònoma de Barcelona, Bellaterra 08193, Spain. Tel: (34) 93581 4796, Fax: (34) 93581 2013; CarlosEsteban.Rodriguez@uab.cat

3. Centro de Investigaciones en Electroquímica y Energía Química, Universidad de Costa Rica, 2060 Costa Rica; rblanco@cariari.ucr.ac.cr

Received 28-XI-2008. C Corrected 28-III-2009. Accepted 30-VI-2009.

\begin{abstract}
Microbial contamination of fuel has been the cause of several problems in transportation and storage of these products. Due to the lack of previous studies related to these problems in Costa Rica, bacterial quality was evaluated biannually in automotive fuels stored in the four oil distribution facilities of the Costa Rican Petroleum Refinery (RECOPE). In 12 oil storage tanks, for a total of 96 samples, mesophilic, heterotrophic aerobic/facultative counts (ASTM D6974-04) and identification of bacteria presented in regular gas, premium gas and diesel from the bottom and superior part of the tanks were done; in the samples containing an aqueous phase, sulfate reducing bacteria (SRB) were also quantified by the most probable number technique (MPN), according to the ASTM D4412-84 standard. The higher contamination was shown at the bottom of the tanks (populations up to $10^{4} \mathrm{UFC} / 1$ ), especially if there was accumulated water, in which case populations reached $10^{8} \mathrm{UFC} / 1$. The most contaminated fuel was diesel (counts up to $10^{4} \mathrm{UFC} / \mathrm{l}$ ), whereas the less contaminated was premium gas. The less contaminated fuels were from the facilities of La Garita and Barranca, whereas the most contaminated were from Ochomogo. Nevertheless, the quantified populations did not cause significant alteration in quality physicochemical parameters in the samples analyzed. A total of 149 bacterial strains were isolated, 136 (91.3\%) Gram positive and $13(8.7 \%)$ Gram negative. The most frequent genera were Staphylococcus $(24.0 \%)$, Micrococcus (21.9\%), Bacillus (18.8\%) and Kocuria (11.5\%) among Gram positive bacteria and Pseudomonas (7.3\%) among Gram negative bacteria. The majority of these genera have been found as fuel contaminants or even as degraders of this kind of products; nevertheless, some species for which their appearance or growth in hydrocarbons have not been described were found with low frequencies. SRB were present in counts up to $10^{5}$ MPN/l in $42.9 \%$ of water containing samples (including all from diesel tanks), indicating biocorrosion processes risk in fuel transport and storage systems. From the findings in this study it is recommended to give a frequent maintenance to fuel containers, based on continuous drainage and removal of accumulated water, antimicrobial agent addition and microbial quality monitoring in country's fuels. Rev. Biol. Trop. 57 (3): 489-504. Epub 2009 September 30 .
\end{abstract}

Key words: fuel, microbial contamination, fuel storage tanks, sulfate reducing bacteria, biocorrosion.

Microbial contamination of fuel has been the cause of operational problems for many years, nevertheless, its frequency has increased recently, due to many factors such as changes in fuel quality, increasing use of additives which may provide nutrients to microorganisms, and alteration in housekeeping and storage practices (Pitcher 1989).

Microorganisms may be introduced in fuel containers through different ways: during condensation processes in refineries or transported along with dust and water through tank vents 
(Yemashova et al. 2007). Once inside the tanks, some organisms may adhere to wall surface, whereas others settle to the fuel/water interface, usually present at the bottom of the tanks, place with higher microbial activity and where most biodegradation may occur (Yemashova et al. 2007). However, it is often impractical to obtain samples from these locations within fuel systems (Gaylarde et al. 1999). Although the numbers of viable bacteria and fungi recovered from fuel-phase samples are several orders of magnitude smaller than those found in waterphase samples, fuel-phase microorganisms are often the most readily available indicators to evaluate microbial contamination in this kind of products (Yemashova et al. 2007).

The presence of microorganisms in fuel storage systems causes an increase in water content due to potential microbial degradation of hydrocarbons, and their metabolic activity leads to peroxide and acid formation, increase in viscosity, decrease in thermal stability and volatility, as well as increase in suspended solids in the form of sludge and corrosion residues, among others, that may lead to filtration problems, equipment deterioration and a general loss in fuel quality (Kartavtseva et al. 1989, Gaylarde et al. 1999, Yemashova et al. 2007).

Crude oil and its by-products contain nutritive compounds, therefore they represent a favorable environment for microbial growth, which may cause not only hydrocarbon consumption but a detriment in physicochemical and operational properties of products, leading to economic loss and even accidents due to filter saturation and pipeline and equipment corrosion (Gaylarde et al. 1999, Yemashova et al. 2007).

Both, aerobic and anaerobic bacteria, tend to colonize fuel storage and transport equipments. Many species of bacteria, fungi and yeasts have been isolated from fuel, although not all of them are able to grow in hydrocarbons. Among bacteria able to grow in fuel, genera such as Acinetobacter, Alcaligenes, Bacillus, Pseudomonas, Flavobacterium, Aeromonas, Achromobacter, Arthrobacter, Nocardia, Rhodococcus and Micrococcus have been reported (Gaylarde et al. 1999, Emtiazi et al. 2005, Yemashova et al. 2007, Neilson \& Allard 2008). To grow in this environment, microorganisms require the capacity to metabolically transform hydrocarbons in order to employ them as carbon and energy source. Several studies have described biodegradation mechanisms of different hydrocarbons (Yemashova et al. 2007, Neilson \& Allard 2008 ); in the case of alkanes in aerobic conditions, the mechanism involves a terminal hydroxylation followed by dehydrogenations, until forming the respective alcohols, aldehydes and carboxylic acids, or alternatively, a subterminal hydroxylation followed by oxidation to ketones (Neilson \& Allard 2008).

Sulfate reducing bacteria (SRB) are found among anaerobic organisms associated to stored fuels; they include a diverse group of microorganisms able to perform disassimilatory reduction of sulfur compounds such as sulfate, sulfite, thiosulfate, or elemental sulfur, to produce sulfide (Beech \& Gaylarde 1999); even though they are anaerobic, some genera are able to tolerate low oxygen concentrations (Abdollahi \& Wimpenny 1990). Oil and naval industry have been seriously affected by sulfides produced by SRB, since these compounds are implicated, in many ways, in health and environmental problems, but mainly in economical losses due to equipment corrosion (Hamilton 1985, Jack et al. 1992, Beech \& Gaylarde 1999).

Three kinds of fuel are mainly used in automotive industry in Costa Rica: regular gas, premium gas and diesel; they are stored basically in four oil distribution facilities spread around the country, belonging all of them to the same company, but with different climate and atmospheric conditions, which may lead to differences in the microbial contamination level of the fuels. Since no studies have been yet performed, this work aims to make a bacteriological evaluation of automotive stored fuels in Costa Rica, in order to determine their microbiological quality, the populations involved and to establish some recommendations to diminish their contamination. 


\section{MATERIALS AND METHODS}

Sampling sites: The fuel storage tanks of the four oil distribution facilities of the Costa Rican Petroleum Refinery (RECOPE, located in La Garita 9 $9^{\circ} 59^{\prime} 07 \mathrm{~N}, 8^{\circ} 20^{\prime} 17 \mathrm{~W}$; Alto de Ochomogo 9॰53'47 N, 8356’45 W; Moín $9^{\circ} 59^{\prime} 55 \mathrm{~N}, 83^{\circ} 04^{\prime} 35 \mathrm{~W}$ and Barranca $9^{\circ} 59^{\prime} 41$ $\mathrm{N}, 84^{\circ} 43^{\prime} 26 \mathrm{~W}$ ), were sampled according to the norms established by the American Society for Testing and Materials (ASTM). Samples were taken by using Sample Thief (Bacon Bomb) containers (model K27790, Koehler); two ropes were adapted to a sterilized container immediately before sampling, one to act as a holder and the other to activate the opening mechanism. The closed sampler was introduced into the oil tank until completely covered by the fuel and then opened by pulling the rope; when it was filled the rope was released to close the container, and taken out of the tank; the fuel was aseptically transferred to one liter bottles and labeled as "top". The container was washed three times with $80 \%$ ethanol, submerged again into the tank and left to reach the bottom, where a plunger automatically opens to admit the sample; the plunger closes again when the container is withdrawn, forming a tight seal; these samples were labeled as "bottom". A different container was employed for each tank sampled. A semiannual sampling was made in each facility during the years 2006 and 2007; in each one, samples from regular gas tank (Bio Plus Gas), premium gas and diesel were taken from the upper as well as the bottom part of the container. The bottom part samples of the tanks often included an easily appreciated aqueous phase, which was separated and analyzed independently. In total, 96 samples were taken, 32 of each type of fuel, which correspond to 24 from each oil distribution facility. Additional sampling points were the oil dispenser valves, located approximately $0.75 \mathrm{~m}$ above ground level; two samples of these valves from each storage tank were taken (24 samples in total).

Physicochemical parameters: A physicochemical parameter determination used for quality control in Costa Rican fuels was made to each sample: distillation (ASTM D-86), Reid vapor pressure (ASTM D-323), sulfur content (ASTM D-4294), copper corrosion (ASTM D-130), gums content (ASTM D-381), lead content (ASTM D-3237), octane index and number IR correlation, color, water content (ASTM D-4176), density (ASTM D-1298), oxygenated content (ASTM D-5845), benzene content (ASTM D-6277) aromatic content (correlated to ASTM D-1319) and olefins content (correlated to ASTM D-1319) for regular gas and premium gas; distillation (ASTM D-86), cinematic viscosity (ASTM D-445), sulfur content (ASTM D-4294), combustion point (ASTM D-93), Conradson carbon residue (ASTM D-524), nitrogen content (ASTM D-3228), ashes content (ASTM D-482), color (ASTM D-1500), sediment and water content (ASTM D-1796), density (ASTM D-1298), total aromatic content (correlated ASTM D-1319), polinuclear aromatic content (correlated to ASTM D-1319) and cetane index (ASTM D-4737 and D-976) for diesel.

Mesophilic heterotrophic aerobic/facultative bacterial quantification: Enumeration of bacteria of each fuel, was performed following the methodology described by the ASTM D6974-04 standard (ASTM 2004). Briefly, three different fuel aliquots $(200 \mathrm{ml}, 20 \mathrm{ml}$ and $2 \mathrm{ml}$ ) were filtered in sterile nitrocellulose filters $(0.45 \mu \mathrm{m})$. Each filter was washed by filtration with $10 \mathrm{ml}$ of Tween 80 on $0.1 \% \mathrm{~V} / \mathrm{V}$ and three aliquots of $10 \mathrm{ml}$ Ringer solution; the filters were placed on Tripticase Soy Agar (TSA) plates and incubated at $25^{\circ} \mathrm{C}$ for 72 hours, for their posterior count. The samples from the aqueous phase taken from the bottom of the tanks were separated and then bacteria populations were quantified by the plate count methodology using TSA. Only 14 of the samples presented this aqueous phase.

Bacterial strain identification: The different colonial morphotypes of bacteria from TSA plates were purified to new TSA plates. Preliminary identification tests such as Gram 
stain, catalase, oxidase and acid production from glucose were performed. Based on these results, the appropriate miniaturized biochemical-test gallery for identification was chosen; the systems API $20 \mathrm{NE}^{\circledR}$, API STAPH ${ }^{\circledR}$, Biolog GN2 ${ }^{\circledR}$ and Biolog GP2 ${ }^{\circledR}$ were employed. All the galleries were incubated and interpreted according to manufacture's recommendations (bioMérieux, Biolog). All the strains were then stored at $-86^{\circ} \mathrm{C}$ in Eppendorf tubes containing Brain and Heart Infusion Broth (BHIB) supplemented with $20 \%$ glycerol and at present they are stored in the strain collection of the Laboratorio de Investigación en Bacteriología Anaerobia of Universidad de Costa Rica ( ${ }^{\circ}$ LIBA 2269-2418). The frequency of each bacteria species was calculated with the equation $\mathrm{F}=(\mathrm{Ta} / \mathrm{TA}) \cdot 100$, where $\mathrm{Ta}$ is the sample number in which the taxon was found and TA the total number of samples. According to this equation, the species frequencies were classified as: < $10 \%=$ rare, $10 \leq 25 \%=$ low, $25<35 \%=$ frequent $35<50 \%=$ abundant and $>50 \%=$ very abundant (Azedo Loueriro et al. 2005).

SRB quantification: The quantification of SRB was performed to the aqueous phase presented in 14 samples from the bottom of the tanks, according to the most probable number (MPN) technique indicated in the ASTM D4412-84 standard (ASTM 1984). Briefly: 10 $\mathrm{ml}$ aliquots of the water sample were placed in a series of five tubes containing $10 \mathrm{ml}$ of Starkey $2 \mathrm{X}$ medium and $1 \mathrm{ml}$ aliquots in a series of five tubes containing $9 \mathrm{ml}$ of Starkey $1 \mathrm{X}$ medium. Additionally, serial decimal dilutions $\left(10^{-1}-10^{-5}\right)$ were prepared with the sample, and $1 \mathrm{ml}$ aliquots of each dilution were placed in series of five tubes containing Starkey $1 \mathrm{X}$ medium. After inoculation, each tube was sealed employing $3 \mathrm{ml}$ sterile VASPAR in order to create anaerobic conditions and all the tubes were incubated at $25^{\circ} \mathrm{C}$ for 21 days; a positive reaction was determined by the formation of a black precipitated compound which corresponds to iron sulfide. Quantification was accomplished by comparing the number of positive tubes of each series to MPN tables.
Statistical analyses: The bacterial contamination levels at the top and the bottom of the tanks were compared by a t-test analysis for paired samples employing the logarithms of the counts from the pooled data of the three kinds of fuel; a similar analysis was performed to compare the contamination in the aqueous and organic phases from the bottom of the tanks. The differences among bacterial counts from each kind of fuel were compared by an ANOVA test employing the logarithms of the pooled data; similarly, contamination levels in the four oil distribution facilities were compared. All analyses were performed with the statistical software SPSS version 16.0.

\section{RESULTS}

Physicochemical parameters: All the fuel samples showed physicochemical parameters values considered as acceptable according to national standards, with the exception of four premium gas samples, that presented octane numbers below the permitted limit, and five diesel samples, which sulfur content surpassed the upper limit. Nevertheless, those variations in octane number and sulfur content were small if compared to the standard. Permitted values for each parameter as well as the range of obtained values are shown in tables 1 and 2 .

Mesophilic heterotrophic aerobic/facultative bacterial quantification: The results corresponding to the quantification of mesophilic heterotrophic aerobic/facultative bacteria, for the different fuels and the four RECOPE oil distribution facilities are shown in table 3. The higher bacterial contamination was present in the fuel from the bottom of the tanks, if compared to the samples from the top $(\mathrm{t}=3.320$, $\mathrm{p}<0.005)$. Nevertheless, the counts from the aqueous phase accumulated in tanks were even higher $(\mathrm{t}=6.160, \mathrm{p}<0.05$, table 4$)$.

Although the difference between the three kinds of fuel was not significant $(\mathrm{p}=0.258)$, diesel showed the higher degree of microbial contamination, since $13(40.6 \%)$ out of the 32 samples presented counts that were equal or 
TABLE 1

Physicochemical parameters of regular and premium gas stored in four oil distribution facilities of RECOPE, Costa Rica

\begin{tabular}{|c|c|c|c|}
\hline \multirow[t]{2}{*}{ Parameter } & \multirow[t]{2}{*}{ Permitted values (National normative) } & \multicolumn{2}{|c|}{ Value range } \\
\hline & & Regular gas & Premium gas \\
\hline Distillation, initial temperature, ${ }^{\circ} \mathrm{C}$ & I.P. & $31.1-38.3$ & $31.4-37.0$ \\
\hline Distillation temperature at $10 \%,{ }^{\circ} \mathrm{C}$ & $\leq 70$ & $51.0-60.6$ & $50.5-59.7$ \\
\hline Distillation, temperature at $50 \%,{ }^{\circ} \mathrm{C}$ & $77-140$ & $94.2-112.3$ & $82.4-115.1$ \\
\hline Distillation, temperature at $90 \%,{ }^{\circ} \mathrm{C}$ & $\leq 190$ & $149.5-173.2$ & 144.9-178.6 \\
\hline Distillation, final point temperature, ${ }^{\circ} \mathrm{C}$ & $\leq 225$ & $182.9-213.0$ & $178.2-215.2$ \\
\hline Distillation residue, $\%$ & $\leq 2$ & $0.4-1.0$ & $0.6-1.0$ \\
\hline Reid vapor pressure at $37.8^{\circ} \mathrm{C}$ & $\leq 69$ & $49.5-67.6$ & $51.0-68.7$ \\
\hline Sulfur content, $\% \mathrm{~m} / \mathrm{V}$ & 0.10 & $0.027-0.081$ & $0.020-0.085$ \\
\hline Copper corrosion & Standard 1 max & $1 \mathrm{~A}$ & $1 \mathrm{~A}$ \\
\hline Gum content, $\mathrm{mg} / 100 \mathrm{ml}$ & 5 & $<1$ & $<1$ \\
\hline Lead content, $\mathrm{g} / \mathrm{l}$ & 0.013 & 0.00023 & 0.00023 \\
\hline Octane index & $\geq 83$ (regular) $\geq 89.0$ (premium) & $84.6-89.0$ & $89.0-90.6$ \\
\hline Octane number & $\geq 88$ (regular) $\geq 95.0$ (premium) & $89.0-95.0$ & $94.0-96.5$ \\
\hline Color & Orange (regular) Red (premium) & Orange & Red-reddish \\
\hline Water, \% & None & Not detected ${ }^{a}$ & Not detected ${ }^{\mathrm{a}}$ \\
\hline Density at $15^{\circ} \mathrm{C}, \mathrm{kg} / \mathrm{m}^{3}$ & I.P. & $733-751$ & $733-756$ \\
\hline Oxygenated content, $\%$ & $\leq 2$ (regular) I.P. (premium) & $0.00-3.01$ & $0.85-2.61$ \\
\hline Benzene content, $\%$ & I.P. & $0.94-1.19$ & $0.70-1.83$ \\
\hline Aromatic content, $\%$ & I.P. & $20.6-29.2$ & $23.4-31.5$ \\
\hline Olefins content, $\%$ & I.P. & $15.5-23.2$ & $15.5-26-6$ \\
\hline
\end{tabular}

a. Aqueous phase present in some samples of the bottom of the containers was not considered.

I.P.: Inexistent parameter.

over $10^{2} \mathrm{CFU} / 1$, whereas this results were presented in only ten $(31.3 \%)$ samples of regular gas and eight $(25 \%)$ of premium gas. Likewise, the lowest bacterial levels were obtained for premium gas, since 24 (75\%) out of 32 samples presented counts of $10^{1} \mathrm{CFU} / 1$ or less, situation showed only in $22(68.7 \%)$ samples of regular gas and $19(59.4 \%)$ of diesel (table 3$)$.

Six out of 14 residual water samples presented counts over $10^{6} \mathrm{CFU} / \mathrm{l}$. Similarly, a higher contamination of diesel was shown in these samples, since five out of the six most contaminated corresponded to all diesel tanks.

Respect to microbial quality by oil distribution facilities, the bacterial counts were not significantly different $(\mathrm{p}=0.124)$; however, the tendency showed that the "cleaner" fuels came from the facility of La Garita, where seven
$(29.2 \%)$ out of 24 samples presented negative counts $(<5 \mathrm{CFU} / \mathrm{l})$ and only five $(20.8 \%)$ equal or over $10^{2} \mathrm{CFU} / \mathrm{l}$. On the other hand the facility with the highest contamination was Ochomogo, where 12 (50\%) samples presented counts over $10^{2} \mathrm{CFU} / 1$, whereas only four $(16.7 \%)$ showed negative counts; slightly less contaminated was the facility of Moín (33.3\% counts $\geq 10^{2} \mathrm{CFU} / 1,20.8 \%$ negative counts, table 3). Similarly, the facility of Ochomogo presented the majority of water containing samples $(10 / 12=83.3 \%$ of the samples from this facility; $10 / 14=71.4 \%$ of the water containing samples, table 4). The same trends related to the most contaminated fuel (diesel) and facility (Ochomogo) were presented in the samples taken from the dispenser valves of the storage tanks (data not shown). 
TABLE 2

Physicochemical parameters of diesel stored in four oil distribution facilities of RECOPE, Costa Rica.

\begin{tabular}{|c|c|c|}
\hline Parameter & Permitted values (National normative) & Value range \\
\hline Distillation, initial temperature, ${ }^{\circ} \mathrm{C}$ & I.P. & $170.9-196.9$ \\
\hline Distillation temperature at $10 \%,{ }^{\circ} \mathrm{C}$ & I.P. & 212.9-233.2 \\
\hline Distillation, temperature at $50 \%,{ }^{\circ} \mathrm{C}$ & I.P. & $277.2-290.6$ \\
\hline Distillation, temperature at $90 \%,{ }^{\circ} \mathrm{C}$ & $\leq 360$ & $329.8-349.3$ \\
\hline Distillation, final point temperature, ${ }^{\circ} \mathrm{C}$ & I.P. & $359.4-375.0$ \\
\hline Distillation residue, $\%$ & $\leq 2$ & $1.1-1.4$ \\
\hline Cinematic viscosity at $40^{\circ} \mathrm{C}$, cSt & $1-9-5.3$ & $2.97-3.42$ \\
\hline Sulfur content, $\% \mathrm{~m} / \mathrm{V}$ & 0.35 & $0.16-0.46$ \\
\hline Inflammation point, ${ }^{\circ} \mathrm{C}$ & $\geq 52$ & $62.3-80.5$ \\
\hline Conradson carbon residue, $\%$ & $\leq 0.2$ & $0.0011-0.0031$ \\
\hline Nitrogen content, $\% \mathrm{~m} / \mathrm{m}$ & I.P. & $0.03-0.35$ \\
\hline Ashes content, $\%$ & $\leq 0.01$ & $0.001-0.003$ \\
\hline Color & Standard 3 & $1.0-2.0$ \\
\hline Water and sediment content, $\% \mathrm{~V} / \mathrm{V}$ & $\leq 0.05$ & $<0.05^{\mathrm{a}}$ \\
\hline Density at $15^{\circ} \mathrm{C}, \mathrm{kg} / \mathrm{m}^{3}$ & I.P. & $852-866$ \\
\hline Total aromatic content, $\% \mathrm{~m} / \mathrm{m}$ & I.P. & $20.8-26.1$ \\
\hline Polinuclear aromatic content, $\% \mathrm{~m} / \mathrm{m}$ & I.P. & $3.9-7.1$ \\
\hline Cetane Index, ASTM D-976 & $\geq 45$ & $46.4-49.1$ \\
\hline Cetane Index, ASTM D-4737 & $\geq 45$ & $45.0-48.6$ \\
\hline
\end{tabular}

Bacteria identification: A total of 149 bacterial strains were isolated from 96 fuel samples, which corresponds to an average of 1.6 strains per sample; $136(91.3 \%)$ corresponded to Gram positive microorganisms of different morphologies (cocci, rods, coccobacilli), whereas $13(8.7 \%)$ corresponded to Gram negative bacilli.

Among Gram positive bacteria (table 5) the most frequent genera were Staphylococcus (32 strains), Micrococcus (26 strains) and Bacillus (28 strains), isolated from $24.0 \%$, $21.9 \%$ and $18.8 \%$ of the samples; these genera were considered of low frequency $(10 \leq 25 \%)$, but close to the value that would consider them as "frequent" ( $25 \leq 35 \%$, Azedo Loureiro et al. 2005). Ten different species of Staphylococcus were found, S. haemolyticus (six strains) being the most frequent, whereas seven species were found of the genus Bacillus, B. cereus/thuringiensis and $B$. megaterium being the most frequent (four strains each). On the other hand, Micrococcus was identified to genus level. Less frequent genera included Kocuria (11 strains), Rhodococcus (six strains) and Corynebacterium (six strains), isolated from $11.5 \%, 6.3 \%$ and $5.2 \%$ of the samples, respectively. Fifteen additional genera were isolated with frequencies lower than $3 \%$ (table 5).

Among Gram negative bacilli, the most frequent genus was Pseudomonas (eight strains), isolated from $7.3 \%$ of the samples, and included the species $P$. pseudoalcaligenes, $P$. fluorescens and $P$. aeruginosa, the two latter being the most frequent $(3.1 \%$ each). The remaining strains belonged to the species Brevundimonas vesicularis, Burkholderia cepacia, Comamonas acidovorans, Flavimonas oryzihabitans and Moraxella sp., all of them with isolation frequency of $1 \%$.

A total of six strains $(4.0 \%)$ could not be identified with the methodology employed in this study. 
TABLE 3

Mesophilic heterotrophic aerobic/facultative bacterial counts in fuels from storage tanks (CFU/l). ${ }^{a}$

\begin{tabular}{|c|c|c|c|c|c|}
\hline \multirow{2}{*}{ Oil distribution facility } & \multirow{2}{*}{ Sample type } & \multicolumn{4}{|c|}{ Sampling ${ }^{b}$} \\
\hline & & $\mathrm{I}-2006$ & II-2006 & $\mathrm{I}-2007$ & II-2007 \\
\hline \multirow[t]{6}{*}{ Ochomogo } & Regular, top & $5.0 \times 10^{0}$ & $1.3 \times 10^{1}$ & $1.5 \times 10^{1}$ & $2.5 \times 10^{2}$ \\
\hline & Regular, bottom & $1.0 \times 10^{1}$ & $9.3 \times 10^{3}$ & $5.0 \times 10^{2}$ & $1.8 \times 10^{2}$ \\
\hline & Premium, top & $3.0 \times 10^{1}$ & $<5$ & $<5$ & $5.5 \times 10^{1}$ \\
\hline & Premium, bottom & $1.1 \times 10^{2}$ & $2.8 \times 10^{1}$ & $1.0 \times 10^{2}$ & $<5$ \\
\hline & Diesel, top & $1.9 \times 10^{2}$ & $2.5 \times 10^{1}$ & $<5$ & $5.0 \times 10^{2}$ \\
\hline & Diesel, bottom & $3.0 \times 10^{2}$ & $1.4 \times 10^{3}$ & $3.0 \times 10^{2}$ & $2.8 \times 10^{4}$ \\
\hline \multirow[t]{6}{*}{ La Garita } & Regular, top & $1.6 \times 10^{1}$ & $1.1 \times 10^{1}$ & $5.0 \times 10^{1}$ & $1.1 \times 10^{1}$ \\
\hline & Regular, bottom & $1.9 \times 10^{2}$ & $2.5 \times 10^{1}$ & $2.7 \times 10^{1}$ & $5.5 \times 10^{1}$ \\
\hline & Premium, top & $<5$ & $<5$ & $<5$ & $5.0 \times 10^{0}$ \\
\hline & Premium, bottom & $9.3 \times 10^{1}$ & $1.1 \times 10^{2}$ & $<5$ & $<5$ \\
\hline & Diesel, top & $5.0 \times 10^{1}$ & $<5$ & $<5$ & $6.0 \times 10^{2}$ \\
\hline & Diesel, bottom & $6.5 \times 10^{2}$ & $5.0 \times 10^{1}$ & $2.5 \times 10^{1}$ & $6.0 \times 10^{2}$ \\
\hline \multirow[t]{6}{*}{ Barranca } & Regular, top & $3.5 \times 10^{2}$ & $<5$ & $<5$ & $5.0 \times 10^{0}$ \\
\hline & Regular, bottom & $<5$ & $<5$ & 5 & $8.7 \times 10^{1}$ \\
\hline & Premium, top & $6.8 \times 10^{2}$ & $2.5 \times 10^{1}$ & $2.5 \times 10^{1}$ & $2.0 \times 10^{1}$ \\
\hline & Premium, bottom & $6.3 \times 10^{2}$ & $1.2 \times 10^{2}$ & $2.5 \times 10^{1}$ & $5.0 \times 10^{0}$ \\
\hline & Diesel, top & $3.0 \times 10^{2}$ & $<5$ & $5.0 \times 10^{1}$ & $<5$ \\
\hline & Diesel, bottom & $<5$ & $<5$ & $1.0 \times 10^{1}$ & $6.0 \times 10^{2}$ \\
\hline \multirow[t]{6}{*}{ Moín } & Regular, top & $2.5 \times 10^{1}$ & $<5$ & $2.2 \times 10^{2}$ & $1.5 \times 10^{2}$ \\
\hline & Regular, bottom & $5.5 \times 10^{2}$ & $5.0 \times 10^{1}$ & $1.5 \times 10^{1}$ & $1.9 \times 10^{2}$ \\
\hline & Premium, top & $<5$ & $2.7 \times 10^{1}$ & $1.0 \times 10^{1}$ & $5.0 \times 10^{0}$ \\
\hline & Premium, bottom & $2.5 \times 10^{2}$ & $5.0 \times 10^{1}$ & $2.0 \times 10^{2}$ & $1.0 \times 10^{1}$ \\
\hline & Diesel, top & $<5$ & $3.0 \times 10^{1}$ & $<5$ & $1.0 \times 10^{2}$ \\
\hline & Diesel, bottom & $2.8 \times 10^{2}$ & $<5$ & $1.5 \times 10^{1}$ & $1.0 \times 10^{1}$ \\
\hline
\end{tabular}

a Significant differences between counts from top and bottom of the tanks $(t=3.320, p<0.05)$; not significant between the three kinds of fuel $(\mathrm{p}=0.258)$ or between the oil distribution facilities $(\mathrm{p}=0.124)$.

${ }^{\mathrm{b}} \mathrm{I}$, first semester and II, second semester sampling of the respective year.

SRB quantification: SRB have been detected only in aqueous phase (Bento \& Gaylarde 1996), therefore just 14 samples were appropriated for their quantification, employing the water layer accumulated at the bottom of the tanks: five of diesel, five of regular gas and four of premium gas. Six samples (42.9\%) presented detectable counts, which included the five samples from diesel tanks, all of them with counts over $10^{3} \mathrm{MPN} / 1$ (table 4).

\section{DISCUSSION}

Mesophilic heterotrophic aerobic/facultative bacterial quantification and physicochemical parameters: This work is the first bacteriological survey on fuels in Costa Rica, as a first contribution for the establishment of microbiological standards relative to the quality of the gasoline distributed around the country, and the knowledge of the range and 
TABLE 4

Mesophilic heterotrophic aerobic/facultative bacterial counts and SRB enumeration in aqueous samples from fuel storage tanks

$\begin{array}{lccc}\text { Oil distribution facility } & \text { Water phase origin } & \text { Bacteria counts (UFC/l) } & \text { SRB (MPN/l) } \\ \text { Ochomogo (I-06)a } & \text { Diesel } & 2.4 \times 10^{7} & 7.9 \times 10^{5} \\ \text { Ochomogo (I-06) } & \text { Regular } & 3.0 \times 10^{4} & <2 \\ \text { Ochomogo (I-06) } & \text { Premium } & <10 & <2 \\ \text { Ochomogo (II-06) } & \text { Diesel } & 7.5 \times 10^{8} & 4.9 \times 10^{5} \\ \text { Ochomogo (II-06) } & \text { Regular } & 3.3 \times 10^{5} & <2 \\ \text { Moín (II-06) } & \text { Regular } & 1.0 \times 10^{5} & <2 \\ \text { Moín (II-06) } & \text { Premium } & 1.0 \times 10^{4} & <2 \\ \text { Ochomogo (I-07) } & \text { Diesel } & 1.7 \times 10^{6} & 2.8 \times 10^{3} \\ \text { Ochomogo (I-07) } & \text { Regular } & 1.0 \times 10^{4} & 7.0 \times 10^{1} \\ \text { Ochomogo (I-07) } & \text { Premium } & 1.0 \times 10^{4} & <2 \\ \text { Ochomogo (II-07) } & \text { Regular } & 3.0 \times 10^{5} & <2 \\ \text { Ochomogo (II-07) } & 3.0 \times 10^{7} & 2.4 \times 10^{3} \\ \text { Barranca (II-07) } & \text { Diesel } & 2.3 \times 10^{8} & 1.6 \times 10^{4} \\ \text { Moín (II-07) } & \text { Diesel } & 1.0 \times 10^{7} & <2 \\ \text { a Code for correspondent sampling is shown in parenthesis: I, first semester and II, second semester; 06, year 2006; 07, } & & \end{array}$

composition of cultivable bacterial populations present in Costa Rican fuels, according to internationally recognized regulations (ASTM 2004). Even if culture-based approaches can provide useful information, molecular based approaches, such as 16S rRNA gene analyses or FISH, may have provided higher counts of bacteria (Lemke \& Leff 2006).

In general, higher bacterial counts were found in the samples obtained from the bottom of the tanks $(t=3.320, p<0.05)$, but they were even surpassed by the counts from the aqueous phase, which were an average of 3.2 logarithms higher $(\mathrm{t}=6.160, \mathrm{p}<0.05)$; these results correlate previous studies, where microbial populations increase as depth of stored fuel tank column also increases (Pitcher 1989, Yemashova et al. 2007).

Microbiologically, the tendency showed that diesel was the most contaminated kind of fuel; this finding resembles those previously obtained in studies performed in Brazil, where these problems are particularly acute for diesel, which frequently presents an important biomass in the water/hydrocarbon interface (Gaylarde et al. 1999, Bento \& Gaylarde
2001). Major microbiological problems have been attributed to diesel due to several reasons: the presence of a higher additive quantity and variety (Gaylarde et al. 1999), which could act as a micronutrient and carbonated compounds source for microbial growth; inclusion in its composition of more soluble compounds, differing from gasoline, which could allow an easier access of hydrocarbons to microorganisms; and having a mixture of high molecular weight compounds, which do not act as membrane solvents, being therefore less toxic for organisms (Leahy \& Colwell 1990).

Although not statistically different, Ochomogo was the oil distribution facility with the highest bacterial contamination, followed by Moín, whereas La Garita and Barranca were the "cleanest" facilities. Association among this observation and climate conditions such as temperature and rainfall was not found, since Ochomogo and Barranca are the sites with the lower and higher mean temperatures $\left(16.6\right.$ and $26.7^{\circ} \mathrm{C}$, respectively, National Weather Institute, Environment, Energy and Telecommunication Department, Costa Rica), meanwhile, annual precipitations were lower 
TABLE 5

Gram positive bacteria isolated from 96 fuel samples from oil distribution facilities in Costa Rica

\begin{tabular}{|c|c|c|c|c|c|}
\hline Bacterial strain & $\begin{array}{c}\text { Total of } \\
\text { strains (\%) } \\
\text { n=149 }\end{array}$ & $\begin{array}{l}\text { Isolation } \\
\text { frequency } \\
(\%) n=96\end{array}$ & Bacterial strain & $\begin{array}{c}\text { Total of } \\
\text { strains }(\%) \\
n=149\end{array}$ & $\begin{array}{l}\text { Isolation } \\
\text { frequency } \\
(\%) n=96\end{array}$ \\
\hline Actinomyces hordeovulneris & $1(0.7)$ & 1.0 & K. varians & $9(6.0)$ & 9.4 \\
\hline Arthrobacter cumminsii & $2(1.3)$ & 2.1 & Kurthia gibsonii & $1(0.7)$ & 1.0 \\
\hline Bacillus sp. ${ }^{\text {a }}$ & $10(6.7)$ & 9.4 & Kytococcus sedentarius & $1(0.7)$ & 1.0 \\
\hline B. cereus/thuringiensis ${ }^{\mathrm{b}}$ & $4(2.7)$ & 4.2 & Microbacterium maritypicum & $1(0.7)$ & 1.0 \\
\hline B. fastidiosus & $2(1.3)$ & 2.1 & M. saperdae & $1(0.7)$ & 1.0 \\
\hline B. laevolacticus & $2(1.3)$ & 2.1 & Micrococcus sp. ${ }^{\mathrm{a}}$ & $25(16.7)$ & 20.8 \\
\hline B. megaterium & $4(2.7)$ & 4.2 & Micrococcus lylae & $1(0.7)$ & 1.0 \\
\hline B. mycoides & $2(1.3)$ & 2.1 & Paenibacillus macerans & $1(0.7)$ & 1.0 \\
\hline B. pumilus & $3(2.0)$ & 3.1 & Rhodococcus sp. ${ }^{\mathrm{a}}$ & $3(2.0)$ & 3.1 \\
\hline B. racemilacticus & $1(0.7)$ & 1.0 & R. equi & $1(0.7)$ & 1.0 \\
\hline Brevibacterium mcbrellneri & $1(0.7)$ & 1.0 & R. fasciens & $2(1.3)$ & 2.1 \\
\hline Brochothrix campestris & $1(0.7)$ & 1.0 & Staphylococcus sp. ${ }^{\mathrm{a}}$ & $4(2.7)$ & 4.2 \\
\hline Brochothrix thermosphacta & $1(0.7)$ & 1.0 & S. arlettae & $1(0.7)$ & 1.0 \\
\hline Cellulomonas gelida & $1(0.7)$ & 1.0 & S. aureus & $1(0.7)$ & 1.0 \\
\hline \multirow{2}{*}{$\begin{array}{l}\text { Clavibacter michiganensis ss } \\
\text { insidiosus }\end{array}$} & \multirow{2}{*}{$1(0.7)$} & \multirow{2}{*}{1.0} & S. capitis & $2(1.3)$ & 2.1 \\
\hline & & & S. cohnii & $5(3.3)$ & 4.2 \\
\hline Corynebacterium sp. $^{\mathrm{a}}$ & $1(0.7)$ & 1.0 & S. epidermidis & $5(3.3)$ & 4.2 \\
\hline C. glutamicum & $2(1.3)$ & 1.0 & S. haemolyticus & $6(4.0)$ & 5.2 \\
\hline C. nitrophilus & $3(2.0)$ & 3.1 & S. hominis & $2(1.3)$ & 2.1 \\
\hline Deinococcus radiodurans & $1(0.7)$ & 1.0 & S. lugdunensis & $2(1.3)$ & 2.1 \\
\hline $\begin{array}{l}\text { Dermacoccus } \\
\text { nishinomiyaensis }\end{array}$ & $1(0.7)$ & 1.0 & S. sciuri & $2(1.3)$ & 2.1 \\
\hline Globicatella sanguinis & $1(0.7)$ & 1.0 & S. warneri & $2(1.3)$ & 2.1 \\
\hline Kocuria kristinae & $1(0.7)$ & 1.0 & Streptococcus intestinalis & $1(0.7)$ & 1.0 \\
\hline K. rosea & $1(0.7)$ & 1.0 & Tsukamurella inchonensis & $4(2.7)$ & 4.2 \\
\hline
\end{tabular}

a Taxonomy until species level was not possible with the identification methodology employed in this study.

${ }^{b}$ Differentiation between the two species was not possible with the identification methodology employed in this study.

in Ochomogo (1354.4 $\mathrm{mm}$ ) and higher in Moín (3158.4 mm). Nevertheless, a correlation was found, since most of the aqueous-phase containing samples were found in Moín and Ochomogo, mainly in the latter, where $83.3 \%$ of the samples taken from this place presented water (they correspond to $71.4 \%$ of the water containing samples). This could be partially explained because both facilities are located in the higher relative humidity places (87 and $86 \%$, respectively) if compared to La Garita (76\%) and Barranca (81\%), for which it is suggested to enlarge drainage and cleaning frequency of containers in these sites.

Although no acceptable standards for microbial contamination of fuels have been published (Gaylarde et al. 1999), crude oil derivates can be classified as slightly or highly 
contaminated by the number of microorganisms present in the residual water bottoms, about $10^{8}$ bacteria/l are characteristic for slight contamination whereas $10^{9}-10^{11}$ bacteria/l for high contamination (Yemashova et al. 2007). According to this criteria, only $14.3 \%$ of the samples with residual water were considered slightly contaminated, whereas there were no highly contaminated fuels. Similarly, oil products considered as "clean" contain less than $5.0 \times 10^{4}$ microorganisms per liter of product (Yemashova et al. 2007). Based on this, all the fuels analyzed were considered "clean". These results are consistent with the fact that no significant alteration in physicochemical parameters was found, as it is shown in tables 1 and 2, in spite of the fact that some counts were higher than $10^{8}$ bacteria/l in water. Although there are no periodic cleaning plans for tank maintenance in the oil distributing facilities, these findings could reflect good practices related to cleaning techniques and manipulation during fuel transportation, since these procedures constitute important sources of microbial flora.

Even though this study is not enough to establish standards for definitely classifying Costa Rican fuels, the data revealed that, in general terms, they are "clean" and the levels reached by bacterial populations seem not to affect fuel quality, because there were no important changes in the physicochemical parameters evaluated.

Similarly, it is recommended a rigorous control of tank cleaning (increasing its frequency) as well as the permanence time of fuel in storage systems; it is also suggested the addition of antimicrobial agents (Haggett \& Morchat 1992, Bento \& Gaylarde 2001) which are not used in Costa Rica at present.

Continuous investigation on this field is required, because microbial growth in fuel storage and transportation systems could cause problems such as filter saturation, clogging of nozzles and eventually the breakage of the engines. Therefore, it would be important to repeat this study at gas stations, aiming to determine fuel quality just in the moment it is acquired by the consumer, and to perform more bacterial counts at oil distribution facilities to establish standards of microbial quality of the fuels distributed by RECOPE in Costa Rica.

Bacteria identification: The knowledge of bacterial flora in Costa Rican fuels constitutes a pioneer study, not only important for industry and commerce of these products, but for the possibility to find indigenous microorganisms of potential use in bioremediation, as it has been done in different places around the world (Kanaly \& Harayama 2000, Capelli et al. 2001, Kosaric 2001, Rahman et al. 2002a, Bento et al. 2003, Queiroga et al. 2003, Mishra et al. 2004, Boszczyk-Maleszak et al. 2006, Lopes Ferreira et al. 2006, Pinto et al. 2007). It is important to point out that the $16 \mathrm{~S}$ rRNA gene analyses would have given a wider picture of the bacterial diversity present in the samples, including the identification of the not identified strains.

Respect to Gram positive bacteria, the most frequent genera isolated were Staphylococcus, Micrococcus and Bacillus. Staphylococcus has been found occasionally contaminating fuels (Rauch et al. 2006) and strains of S. hominis have been identified as important diesel degraders in soil (Pinto et al. 2007); on the other hand, Micrococcus and Bacillus, both genera of wide environmental distribution, have been identified as common hydrocarbon contaminants in several works (Edmonds \& Cooney 1967, Gaylarde et al. 1999, Bento \& Gaylarde 2001, Rauch et al. 2006, Yemashova et al. 2007). The great resistance to adverse environmental conditions by Micrococcus and the sporulation ability of Bacillus favor their recuperation from fuel, besides it has been reported the ability of some of their species to degrade it, such as Micrococcus sp., Bacillus sp., B. cereus, B. sphaericus, B. fusiformis, $B$. pumilus and B. subtilis (Atlas 1981, Gaylarde et al. 1999, Kosaric 2001, Bento et al. 2003, Queiroga et al. 2003, Pinto et al. 2008), some of which were isolated in the present study.

In lower isolation frequencies were found the genera Kocuria ("low frequency"), Rhodococcus and Corynebacterium ("rare"). 
Kocuria includes microorganisms that previously belonged to the genus Micrococcus (Stackenbrant et al. 1995), therefore it shares the same ecological features which explain its finding in gasoline (Rauch et al. 2006) and potential biodegrading ability has been described in some of its members (Pinto et al. 2007). The same situation is presented in less frequent genera present in Costa Rican fuels: Dermacoccus and Kytococcus (Stackenbrant et al. 1995). On the other hand, Corynebacterium has been previously found as hydrocarbon contaminant and degrader (Atlas 1981, Gaylarde et al. 1999, Rahman et al. 2002, Yemashova et al. 2007), whereas Rhodococcus, a diverse-metabolizing nocardioform actinomycete, is in turn able to use a wide range of hydrophobic compounds as a carbon source, such as hydrocarbons, chlorinated phenols, steroids and crude oil (Correa Bicca et al. 1999, Sharma \& Pant 2000); ability to degrade diesel in concentrations up to $20000 \mathrm{mg} / \mathrm{l}$ has been described (Lee et al. 2006), therefore its presence in fuels is not surprising (Yemashova et al. 2007).

Some Gram positive genera were isolated in lower than 3\% frequencies; many of them have been found in higher or lower level as fuel contaminants, or their ability to degrade different kinds of hydrocarbons has been shown at least: Actinomyces (Gaylarde et al. 1999, Yemashova et al. 2007), Brevibacterium (Gaylarde et al. 1999, Yemashova et al. 2007), Brochothrix (Manab Sarma et al. 2004), Cellulomonas (Radwan et al. 1998, Radwan \& Al-Muteirie 2001, Riis et al. 2003, Rauch et al. 2006, Al-Awadhi et al. 2007), Clavibacter (Bock et al. 1994, Gülensoy \& Álvarez 2000), Deinococcus (Dua et al. 2002, Brim et al. 2006), Kurthia (Kohno et al. 2002, McNamara et al. 2005) and Microbacterium (Schippers et al. 2005, Al-Awadhi et al. 2007). The same happens to Paenibacillus macerans (previously Bacillus macerans, Ash et al. 1995, Rauch et al. 2006), Tsukamurella (previously distributed among Rhodococcus and Corynebacterium species, Finnerty 1992, Erdlenbruch et al. 2001) and Arthrobacter (Rauch et al. 2006), genus for which it has been also demonstrated the promotion of SRB growth through metabolites produced from hydrocarbon oxidation (Koronelli et al. 2001). For Globicatella and Streptococcus, documented isolations from fuel or other hydrocarbon source, are beyond the knowledge of these authors.

Gram negative bacteria presented low isolation frequencies, and all of them belonged to different families of oxidative rods of wide environmental distribution (Juni \& Bøvre 2005, Palleroni 2005, 2005a, Vancanneyt et al. 2005, Willems \& Gilles 2005) and usual presence in fuels (Bento \& Gaylarde 2001). Amongst this group of microorganisms, Pseudomonas was the most frequent genus; all the found species are commonly isolated from environmental samples of water and soil (Palleroni 2005a) which explains their occurrence in fuels, according to several previous studies (Edmonds \& Cooney 1967, Pitcher 1989, Gaylarde et al. 1999, Bento \& Gaylarde 2001, Rauch et al. 2006), especially P. aeruginosa and $P$. fluorescens, the most frequent species in Costa Rican fuels. This genus' metabolic diversity has been described (Palleroni 2005), particularly related to growth in hydrocarbons, for which the possibility of using different species for environmental pollutant removal (including fuels) has been studied (Atlas 1981, Desai \& Banat 1997, Kosaric 2001, Christofi \& Ivshina 2002, Bento et al. 2003, Emtiazi et al. 2005, Guo-liang et al. 2005, Pinto Mariano et al. 2008). In some research this genus has been mentioned, along with Arthrobacter, as the main fuel degraders in soil (Atlas 1981).

The remaining Gram negative genera were isolated in very low frequencies $(1 \%$ each), for which their presence in fuels could be merely casual. Amongst them, stand out Brevundimonas, previously isolated from fuels (Rauch et al. 2006), Burkholderia, for its capability of degrading polycyclic aromatic hydrocarbons (Palleroni 2005) and Comamonas, usually found in highly polluted places containing complex mixtures of organic compounds, and considered of great degrading potential (Willems \& Gilles 2005), for which all of them could be important in stored fuel spoilage. 
None of the identified microorganisms is restricted to fuel environment, nevertheless, the knowledge of indigenous flora in this kind of systems will allow to determine whether the presence of an organism and its impact on fuel is unusual and should be of concern.

To asses the importance of particular microorganisms in fuel deterioration, it is essential to determine their ability to grow, rather than merely exist in these systems (Bento \& Gaylarde 2001); therefore we pretend to evaluate this feature of our isolates in subsequent studies.

SRB quantification: Among anaerobic bacteria, SRB have attracted special attention due to their impact on deterioration processes, since it has been demonstrated their ability to grow in hydrocarbons as the only organic substrate (Aeckersberg et al. 1991, 1998, Rueter et al. 1994, Gaylarde et al. 1999, Spormann \& Widdel 2000, Kleikemper et al. 2002, Yemashova et al. 2007) and also to promote corrosive processes (Hamilton 1985, Pitcher 1989, Beech \& Gaylarde 1999). These microorganisms are favored in low oxygen concentration environments, therefore the bottom of the tanks constitutes an optimal place for their multiplication, due to the low oxygen diffusion in hydrocarbons and the height of fuel layer. The formation of galvanic cells by massive growth of SRB makes the corrosive process much worse than just the effect of hydrogen sulfide on metals (ASTM 1984), which can cause inner corrosion in fuel transportation machines, besides the harmful effects on useful live of car tanks. On the other hand, corrosion may promote the increase of other microbial populations, through liberation of metallic ions required for their growth (Yemashova et al. 2007).

It is rare to find SRB as gasoline contaminants, which could be explained by the toxic effect of hydrocarbons that compose this kind of fuel (Gaylarde et al. 1999); this observation agrees the findings in this study, where only in one out of the nine water samples from regular or premium gas tanks presented a detectable count by MPN technique. Nevertheless, SRB were found in diesel tanks containing water residue, with populations in the order of $10^{3}$ $10^{5} \mathrm{MPN} / 1$, similarly to previous surveys in Brazil, where they were found in storage tanks, although they were absent in places without aqueous phase, such as bus tanks and injectors (Gaylarde et al. 1999, Bento \& Gaylarde 2001). Just in order to compare, in the present study, SRB were found in $42.9 \%$ of tanks with residual water, whereas in a previous report in ship tanks, they were found in only $17 \%$ of samples (Neihof \& May 1983).

The isolation of Arthrobacter from one of the diesel samples is consistent to SRB presence, according to previous work (Koronelli et al. 2001), nevertheless it seems adventured to affirm that the search for this bacterial genus could be an indicator of potential growth of SRB in fuel storage tanks (Koronelli et al. 2001), since it was not isolated from the remaining SRB-positive tanks.

Several diesel samples presented slightly superior values of sulfur content, if compared to the standard; nevertheless no correlation was found between these samples and the other positive for SRB, because they did not present residual water phase; it is probable that eventual presence of water at the bottom of the tanks containing excess of sulfur would show higher counts than the reported in this study.

It is important to consider that not only SRB are implicated in microbiological corrosion processes, but also different bacterial groups and even fungi (Beech \& Gaylarde 1999), since microbial growth induces located corrosion in fuel storage tanks, thanks to the effect of organic acids released as metabolites from hydrocarbon degradation (Bento et al. 2005) or through anticorrosive agents consumption (Muthukumar et al. 2007).

To date, there are not official standards related to allowed SRB populations in fuel systems, and although the values obtained were lower than $10^{6} \mathrm{MPN} / 1$, the demonstration of the presence of this bacteria in tanks, is a warning signal of imminent danger, since depending on permanence time of water at the bottom of the tanks, SRB population could increase, which 
would increase, in parallel, the risk of biocorrosion in fuel storage containers.

The findings of this study stand out the importance of giving an adequate maintenance to containers, especially diesel tanks, based on the addition of biocide agents, but mainly in continuous drainage and removal of accumulated water, aiming to increase useful life of storage and transportation equipment, as well as engine components of final users.

\section{ACKNOWLEDGMENTS}

The authors thank Ivannia Cordero and Daniel Segura for the technical support during the execution of the project and Vicerrectoría de Investigación of the Universidad de Costa Rica for the economical support (project 803-A6111). We especially thank María Laura Arias for the critical review of this manuscript.

\section{RESUMEN}

Se evaluó semestralmente durante dos años la calidad bacteriana de los combustibles almacenados en los cuatro planteles de la Refinadora Costarricense de Petróleo (Costa Rica). Para un total de 96 muestras se realizaron recuentos (norma ASTM D6974-04) e identificación de las bacterias presentes en gasolina regular, gasolina súper y diesel en los niveles superior e inferior de los tanques contenedores; en las muestras con fase acuosa se cuantificaron las bacterias reductoras de sulfato (SRB, norma ASTM D4412-84). La mayor contaminación se observó en el fondo de los tanques, sobretodo si se presentó una capa de agua almacenada. El diesel fue el combustible más contaminado, sin embargo, no se observó alteración importante en los parámetros fisicoquímicos de las muestras evaluadas. Se aislaron 149 cepas, 136 (91.3\%) Gram positivas y 13 (8.7\%) Gram negativas; los géneros más frecuentes fueron Staphylococcus (24.0\%), Micrococcus (21.9\%), Bacillus (18.8\%), Kocuria (11.5\%) y Pseudomonas $(7.3 \%)$. Con bajas frecuencias se encontraron algunas especies para las que no se ha descrito su aparición o crecimiento en hidrocarburos. Las SRB se presentaron con recuentos de hasta $10^{5} \mathrm{MPN} / 1$ en un $42.9 \%$ de las muestras con agua residual, principalmente en diesel, lo cual es indicativo de alerta por biocorrosión. A partir de los resultados se recomienda dar un mantenimiento frecuente a los contenedores, la adición de compuestos antimicrobianos y el monitoreo de la calidad microbiana de los combustibles del país.
Palabras clave: combustibles, contaminación microbiana, tanques de almacenamiento, bacterias reductoras de sulfato, biocorrosión.

\section{REFERENCES}

Abdollahi, H. \& J.W.T. 1990. Wimpenny. Effects of oxygen on the growth of Desulfovibrio desulfuricans. J. Gen. Microbiol. 136: 1025-1030.

Aeckersberg, F., F. Bak \& F. Widdel. 1991. Anaerobic oxidation of saturated hydrocarbons to $\mathrm{CO}_{2}$ by a new type of sulfate-reducing bacterium. Arch. Microbiol. 156: 5-14.

Aeckersberg, F., F. Rainey \& F. Widdel. 1998. Growth, natural relationships, cellular fatty acids and metabolic adaptation of sulfate-reducing bacteria that utilize long-chain alkanes under anoxic conditions. Arch. Microbiol. 170: 361-369.

Al-Awadhi, H., R.H.D. Sulaiman, H.M. Mahmoud \& S.S. Radwan. 2007. Alkaliphilic and halophilic hydrocarbon-utilizing bacteria from Kuwaiti coasts of the Arabian Gulf. Appl. Microbiol. Biotechnol. 77: 183-186.

Ash, C., F.G. Priest \& M.D. Collins. 1995. Paenibacillus alvei comb. nov., Paenibacillus amylolyticus comb. nov., Paenibacillus azotofixans comb. nov., Paenibacillus gordonae comb. nov., Paenibacillus larvae comb. nov., Paenibacillus macerans comb. nov., Paenibacillus macquariensis comb. nov., Paenibacillus pubuli comb. nov., Paenibacillus pulvifaciens comb. nov. and Paenibacillus validus comb. nov., Validation of the publication of new names and new combinations previously effectively published outside the IJSB, List no. 52. Int. J. Syst. Bacteriol. 45: 197-198.

ASTM. 1984. D 4412-84 R02 Standard test methods for sulfate-reducing bacteria in water and water-formed deposits, p. 1-11. In Subcommittee D19.24 (eds). Annual Book of ASTM Standards Vol 11.02. ASTM International, West Conshohocken, Pennsylvania, USA.

ASTM. 2004. D 6974-04 Standard practice for enumeration of viable bacteria and fungi in liquid fuels-filtration and culture procedures, p. 1-5. In Subcommittee D02.14 (eds). Annual Book of ASTM Standards Vol 05.04. ASTM International, West Conshohocken, Pennsylvania, USA.

Atlas, R.M. 1981. Microbial degradation of petroleum hydrocarbons: an environmental perspective. Microbiol. Rev. 45: 180-209. 
Azedo Loueriro, S.T., M.A. de Queiroz Cavalcanti, R. Pereira Neves \& J.Z. de Oliveira Passavante. 2005. Yeasts isolated from sand and sea water in the beaches of Olinda, Pernambuco State, Brazil. Braz. J. Microbiol. 36: 333-337.

Beech, I.B. \& C.C. Gaylarde. 1999. Recent advances in the study of biocorrosion-An overview. Rev. Microbiol. 30: $177-190$.

Bento, F.M., I.B. Beech, C.C. Gaylarde, G.E. Englert \& I.L. Muller. 2005. Degradation and corrosive activities of fungi in a diesel-mild steel-aqueous system. World J. Microbiol. Biotechnol. 21: 135-142.

Bento, F.M. \& C.C. Gaylarde. 1996. Microbial contamination of stored diesel oil in Brazil. Rev. Microbiol. 27: 192-196.

Bento, F.M. \& C.C. Gaylarde. 2001. Biodeterioration of stored diesel oil: studies in Brazil. Internat. Biodet. Biodegrad. 47: 107-112.

Bento, F.M., F.A. de Oliveira Camargo, B. Okeke \& W.T. Frankenberger-Júnior. 2003. Bioremediation of soil contaminated by diesel oil. Braz. J. Microbiol. 34 (Suppl. 1): 65-68.

Bock, M., K. Bosecker \& W. Dott. 1994. Isolation and characterization of heterotrophic, aerobic bacteria from oil storage caverns in northern Germany. Appl. Microbiol. Biotechnol. 42: 463-468.

Boszczyk-Maleszak, H., A. Zabost, D. Wolicka \& J. Kacieszczenko. 2006. Effectiveness of biodegradation of petroleum products by mixed bacterial populations in liquid medium at different $\mathrm{pH}$ values. Pol. J. Microbiol. 55: 69-73.

Brim, H., J.P. Osborne, H.M. Kostandarithes, J.K. Fredrickson, L.P. Wackett \& M.J. Daly. 2006. Deinococcus radiodurans engineered for complete toluene degradation facilitates $\mathrm{Cr}(\mathrm{VI})$ reduction. Microbiology. 152: 2469-2477.

Capelli, S.M., J.P. Busalmen \& S.R. de Sánchez. 2001. Hydrocarbon bioremediation of a mineral-base contaminated waste from crude oil extraction by indigenous bacteria. Internat. Biodet. Biodegrad. 47: 233-238.

Christofi, N. \& I.B. Ivshina. 2002. Microbial surfactants and their use in field studies of soil remediation. J. Appl. Microbiol. 93: 915-929.

Correa Bicca, F., L. Colombo Fleck \& M.A. Záchia Ayub. 1999. Production of biosurfactant by hydrocarbon degrading Rhodococcus ruber and Rhodococcus erythropolis. Rev. Microbiol. 30: 231-236.
Desai, J. \& I.M. Banat. 1997. Microbial production of surfactants and their commercial potential. Microbial. Mol. Biol. Rev. 61: 47-64.

Dua, M., A. Singh, N. Sethunathan \& A.K. Johri. 2002. Biotechnology and bioremediation: successes and limitations. Appl. Microbiol. Biotechnol. 59: 143152.

Edmonds, P. \& J.J. Cooney. 1967. Identification of microorganisms isolated from jet fuel systems. Appl. Microbiol. 15: 411-416.

Emtiazi, G., H. Shakarami, I. Nahvi \& S.H. Mirdamadian. 2005. Utilization of petroleum hydrocarbons by Pseudomonas sp. and transformed Escherichia coli. Afr. J. Biotechnol. 4: 172-176.

Erdlenbruch, B.N.S., D.P. Kelly \& J.C. Murrell. 2001. Alkanesulfonate degradation by novel strains of Achromobacter xylosoxidans, Tsukamurella wratislaviensis and Rhodococcus sp., and evidence for an ethanesulfonate monooxygenase in A. xilosoxidans strain AE4. Arch. Microbiol. 176: 406-414.

Finnerty, W.R. 1992. The biology and genetics of the genus Rhodococcus. Annu. Rev. Microbial. 46: 193-218.

Gaylarde, C.C., F.M. Bento \& J. Kelley. 1999. Microbial contamination of stored hydrocarbon fuels and its control. Rev. Microbiol. 30: 1-10.

Gülensoy, N. \& P.J.J. Álvarez. 2000. Diversity and correlation of specific aromatic hydrocarbon biodegradation capabilities. Biodegradation. 10: 331-340.

Guo-liang, Z., W. Yue-ting, Q. Xin-ping \& M. Qin. 2005. Biodegradation of crude oil by Pseudomonas aeruginosa in the presence of rhamnolipids. J. Zhejiang Univ. SCI. 6B: 725-730.

Hagget, R.D. \& R.M. Morchat. 1992. Microbiological contamination: Biocide treatment in naval distillate fuel. Internat. Biodet. Biodegrad. 29: 87-99.

Hamilton, W.A. 1985. Sulphate-reducing bacteria and anaerobic corrosion. Ann. Rev. Microbiol. 39: 195217.

Jack, R.F., D.B. Ringelberg \& D.C. White. 1992. Differential corrosion rates of carbin steel by combinations of Bacillus sp., Hafnia alvei and Desulfovibrio gigas established by phospholipid analysis of electrode biofilm. Corr. Sci. 33: 1843-1853.

Juni, E. \& K. Bøvre. 2005. Genus I. Moraxella, p. 417425. In D.J. Brenner, N.R. Krieg \& J.T. Staley (eds.). Bergey`s Manual of Systematic Bacteriology. Springer, New York, New York, USA. 
Kanaly, R.A. \& S. Harayama. 2000. Biodegradation of high-molecular-weight polycyclic aromatic hydrocarbons by bacteria. J. Bacteriol. 182: 2059-2067.

Kartavtseva, Z.M., E.Z. Koval, V.A. Kalaganov \& N.A. Lyapunova. 1989. Destruction of diesel fuel by microorganisms in circulating systems. Mikrobiol. Zh. 51: 87-93.

Kleikemper, J., M.H. Schroth, W.V. Sigler, M. Schmucki, S.M. Bernasconi \& J. Zeyer. 2002. Activity and diversity of sulfate-reducing bacteria in a petroleum hydrocarbon-contaminated aquifer. Appl. Environ. Microbiol. 68: 1516-1523.

Koronelli, T.V., T.I. Komarova, O.V. Porshneva \& L.F. Tkebuchava. 2001. Extracellular metabolites of hydrocarbon-oxidizing bacteria as substrate for sulfate reduction. Appl. Biochem. Microbiol. 37: 469-472.

Kohno, T., Y. Sugimoto, K. Sei \& K. Mori. 2002. Design of PCR primers and gene probes for general detection of alkane-degrading bacteria. Microbes Environ. 17: 114-121.

Kosaric, N. 2001. Biosurfactants and their application for soil bioremediation. Food Technol. Biotechnol. 39: 295-304.

Leahy, J.G. \& R.R. Colwell. 1990. Microbial degradation of hydrocarbons in the environment. Microbiol. Rev. 54: 305-315.

Lee, M., M.K. Kim, I. Singleton, M. Goodfellow \& T. Lee. 2006. Enhanced biodegradation of diesel oil by a newly identified Rhodococcus baikonurensis EN3 in the presence of mycolic acid. J. Appl. Microbiol. 100: 325-333.

Lemke, M.J. \& L.G. Leff. 2006. Culturability of stream bacteria assessed at the assemblage and population levels. Microb. Ecol. 51: 365-374.

Lopes Ferreira, N., H. Maciel, F. Monot, F. FayolleGuichard \& C.W. Greer. 2006. Isolation and characterization of a new Mycobacterium austroafricanum strain, IFP 2015, growing on MTBE. Appl. Microbiol. Biotechnol. 70: 358-365.

Manab Sarma, P., D. Bhattacharya, S. Krishnan \& B. Lal. 2004. Assessment of intra-species diversity among strains of Acinetobacter baumannii isolated from sites contaminated with petroleum hydrocarbons. Can. J. Microbiol. 50: 405-414.

McNamara, C.J., T.D. Perry IV, R. Leard, K. Bearce, J. Dante \& R. Mitchell. 2005. Corrosion of aluminum alloy 2024 by microorganisms isolated from aircraft fuel tanks. Biofouling 21: 257-265.
Mishra, S., P.M. Sarma \& B. Lal. 2004. Crude oil degradation efficiency of a recombinant Acinetobacter baumannii strain and its survival in crude oil-contaminated soil microcosm. FEMS Microbiol. Lett. 235: 323-331.

Muthukumar, N., S. Maruthamuthu, S. Monahan \& N. Palaniswamy. 2007. Oil soluble corrosion inhibitor on microbiologically influenced corrosion in diesel transporting pipeline. Port. Electrochim. Acta. 25: 319-334.

Neihof, R. \& M. May. 1983. Microbial and particulate contamination in fuel tanks on naval ships. Int. Biodeter. Bull. 19: 59-68.

Neilson, A.H. \& A.S. Allard. 2008. Environmental degradation and transformation of organic chemicals. CRC, Taylor \& Francis, Boca Raton, Florida, USA.

Palleroni, N. 2005. Genus I. Burkholderia, p. 575600. In D.J. Brenner, N.R. Krieg \& J.T. Staley (eds.). Bergey`s Manual of Systematic Bacteriology. Springer, New York, New York, USA.

Palleroni, N. 2005a. Genus I. Pseudomonas, p. 323379. In D.J. Brenner, N.R. Krieg \& J.T. Staley (eds.). Bergey`s Manual of Systematic Bacteriology. Springer, New York, New York, USA.

Pinto Mariano, A., A.P. de Arruda Geraldes Kataoka, D. de Franceschi de Angelis \& D.M. Bonotto. 2007. Laboratory study on the bioremediation of diesel oil contaminated soil from a petrol station. Braz. J. Microbiol. 38: 346-353.

Pinto Mariano, A., D.M. Bonotto, D. de Franceschi de Angelis, M.P. Santos Pirôllo \& J. Contiero. 2008. Biodegradability of commercial and weathered diesel oils. Braz. J. Microbiol. 39: 133-142.

Pitcher, D.G. 1989. Industrial case histories of microbiological fuel contamination-Cause, effect and treatment. Int. Biodet. 25: 207-218.

Queiroga, C.L., L.R. Nascimento \& G.E. Serra. 2003. Evaluation of paraffins biodegradation and biosurfactant production by Bacillus subtilis in the presence of crude oil. Braz. J. Microbiol. 34: 321-324.

Radwan, S.S., H. Al-Awadhi, N.A. Sorkhoh \& I.M. El-Nemr. 1998. Rhizospheric hydrocarbon-utilizing microorganisms as potencial contributors to phytoremediation for oily Kuwati desert. Microbiol. Res. 153: $247-251$.

Radwan, S.S. \& A.S. Al-Muteirie. 2001. Vitamin requirements of hydrocarbon-utilizing soil bacteria. Microbiol. Res. 155: 301-307. 
Rahman, K.S., T. Rahman, P. Lakshmanaperumalsamy \& I.M. Banat. 2002. Occurrence of crude oil degrading bacteria in gasoline and diesel station soils. J. Basic Microbiol. 42: 284-291.

Rahman, K.S., J. Thahira-Rahman, P. Lakshmanaperumalsamy \& I.M. Banat. 2002a. Towards efficient crude oil degradation by a mixed bacterial consortium. Bioresour. Technol. 85: 257-261.

Rauch, M.E., H.W. Graef, S.M. Rozenzhak, S.E. Jones, C.A. Bleckman, R.L. Kruger, R.R. Naik \& M.O. Stone. 2006. Characterization of microbial contamination in United States Air Force aviation fuel tanks. J. Ind. Microbiol. Biotechnol. 33: 29-36.

Riis, V., S. Kleinsteuber \& W. Babel. 2003. Influence of high salinities on the degradation of diesel fuel by bacteria consortia. Can. J. Microbiol. 49: 713-721.

Rueter, P., R. Rabus, H. Wilkes, F. Aeckersberg, F.A. Rainey, H.W. Jannasch \& F. Widdel. 1994. Anaerobic oxidation of hydrocarbons in crude oil by new types of sulphate-reducing bacteria. Nature. 372: 455-458.

Schippers, A., K. Bosecker, C. Spröer \& P. Schumann. 2005. Microbacterium oleivorans sp. nov. and Microbacterium hydrocarbonoxydans sp. nov., novel crude-oil-degrading Gram-positive bacteria. Int. J. Syst. Evol. Microbiol. 55: 655-660.
Sharma, S.L. \& A. Pant. 2000. Biodegradation and conversion of alkanes and crude oil by a marine Rhodococcus sp. Biodegradation. 11: 289-294.

Spormann, A.M. \& F. Widdel. 2000. Metabolism of alkylbenzenes, alkanes, and other hydrocarbons in anaerobic bacteria. Biodegradation. 11: 85-105.

Stackenbrandt, E., C. Koch, O. Gvozdiak \& P. Schumann. 1995. Taxonomic dissection of the genus Micrococcus: Kocuria gen. nov., Nesterenkonia gen. nov., Kytococcus gen. nov., Dermacoccus gen. nov., and Micrococcus Cohn 1872 gen. emend. Int. J. Syst. Bacteriol. 45: 682-692.

Vancanneyt, M., P. Segers, W.R. Abraham \& P. de Vos. 2005. Genus III. Brevundimonas, p. 308-316. In D.J. Brenner, N.R. Krieg \& J.T. Staley (eds.). Bergey`s Manual of Systematic Bacteriology. Springer, New York, New York, USA.

Willems, A. \& M. Gillis. 2005. Genus I. Comamonas, p. 689-696. In D.J. Brenner, N.R. Krieg \& J.T. Staley (eds.). Bergey`s Manual of Systematic Bacteriology. Springer, New York, New York, USA.

Yemashova, N.A., V.P. Murygina, D.V. Zhukov, A.A. Zakharyantz, M.A. Gladchenko, V. Appana \& S.V. Kalyuzhnyi. 2007. Biodeterioration of crude oil and oil derived products: a review. Rev. Environ. Sci. Biotechnol. 6: 315-337. 